\title{
Citation score boosts Australian institute over research funds
}

\begin{abstract}
Sydney. A comparison of the research performance of Australian universities has confirmed the leading role of the Australian National University (ANU) and its major research arm, the Institute of Advanced Studies (IAS) in Canberra. This has boosted the institute's efforts to fend off greater control over its research agenda by the Australian Research Council (ARC).
\end{abstract}

The conclusion is based on bibliometric analysis of papers published by all Australian universities between 1981 and 1994. The analysis, by the Institute for Scientific Information (ISI) in Philadelphia, Pennsylvania, is reported in the latest issue of ISI's Science Watch. It comes at a time when funding pressures are forcing Australian universities to become more competitive.

The IAS/ANU won first place across major disciplines on two measures: 'impact' - average citations per paper - and total citations. According to the analysis, the two institutions had particular strengths in physical sciences, including chemistry, geosciences, engineering and astrophysics. The IAS has seven postgraduate research schools.

The University of Melbourne came a close second overall, dominating the life sciences by leading both rankings in immunology, molecular biology, microbiology, pharmacology, neuroscience, and biology and biochemistry. The University of Sydney took third place as it "showed depth in the total-citations rankings, appearing among the top three in 14 fields".

The ISI ranking will bolster the ANU's defence against recommendations by the ARC that the research council should have greater influence over the university's block funding and research agenda (see Nature 382, 3; 1996). Sue Serjeantson, IAS director, welcomes the independent score as "confirming" the finding of an earlier review of the institute's research activities. "The bibliometric data underpin, but do not replace, the opinion of the 1995 peer reviewers who said no other Australian institution can match our high standards of performance."

The ANU has been trying to discredit the ARC's report, and to put its case direct to the education minister, Senator Amanda Vanstone. Many of the IAS assessors have written to John Howard, the new prime minister, warning that to disregard the recommendations of the ANU's own review would damage the institute's standing.

Meanwhile Max Brennan, the chairman of the ARC, has criticized the ANU for "continuing its media campaign". He says: "It is inappropriate to comment on allegations by representatives and staff of the university while the government is still considering the ARC's advice." Peter Pockley

\section{US companies accused of 'dumping' waste cargoes}

Hong Kong. China has turned away a shipment of 200 tonnes of plastics waste from the United States intended for recycling, following the tightening of regulations to comply with a United Nations (UN) treaty on waste exports. Further shipments could be returned to other countries.

The shipment of plastics waste is now stuck in Hong Kong harbour. Chinese officials say there are shipments of scrap metal awaiting return to the United States, Japan, the United Kingdom and other European countries.

The United States and eastern European countries are already talking to Chinese officials about rejected shipments of medical and allegedly radioactive metal waste. William Chen Ping, a Chinese-American businessman, has been in police custody in Shanghai since 3 June for allegedly importing waste illegally.

The plastics shipment has been returned to the Hong Kong trader that negotiated the deal. The waste includes plastic bags from US supermarket chains, and was rejected by Fujian provincial authorities in May because it was mixed with domestic refuse, including rotting food. Hong Kong All at sea? The Min Hai 451 has been refused permission has so far been unable to return to land its shipment of plastics waste in China. the waste to the United States.

In recent years, China has imported large amounts of plastic, scrap metal, radioactive and medical waste, chiefly from the United States. There have been reports from China of large dumps of foreign waste being created on city outskirts, and of recycling factories in which molten plastic is stirred in open vats without safety controls.

In April, the government passed a law banning the import of waste for disposal, and restricting imports for recycling to a shortlist under a tight permit system controlled by the National Environmental Protection Agency.

A high-profile campaign in China's staterun newspapers has pinpointed the United States as the chief culprit for "using China as a dumping ground". Strong public criticism has been stirred up by shipments of allegedly highly radioactive iron and steel sent from Houston, Texas, to Tianjin, and a load of medical waste allegedly found dumped outside Beijing. But the United States has not been the only culprit; there have also been radioactive metal shipments from Kazakhstan and Kyrgyzstan.

Embarrassed officials at the US supermarket chains from which the plastic originated, including Winn-Dixie, of Florida, say that they had been under the impression that the bags, returned by customers, were recycled into garden furniture by Trex, a Mobil subsidiary based in Virginia.

Hong Kong's environmental authorities have refused to accept the returned waste, and say the United States has a moral obligation to take it back. But the US exporter, ICP Industries, says the Hong Kong firm knew the purchase was "dirty", and denies any responsibility for problems with China.

Ironically, the situation has arisen partly because China has incorporated a UN convention into its law faster than either Hong Kong or the United States. Under the Basle Convention on Control of Transboundary Movement of Hazardous

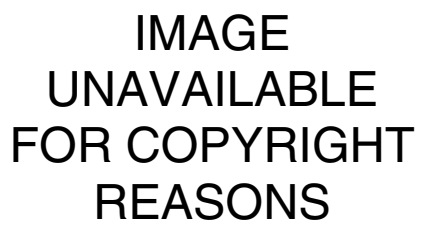

Wastes and their Disposal, signed in 1989, all exported waste must have an export permit, as well as import approval from its destination.

The United States, despite being a signatory of the convention, has not yet ratified it. The US consulate in Hong Kong has bowed to pressure from the colony's government and offered to help find a company in the United States willing to re-import the plastic. The US Environmental Protection Agency has also been recruited to alert US companies to the change in Chinese law.

Meanwhile officials in Shenzhen, a Chinese town close to the border with Hong Kong, say they will return to the colony another nine loads of scrap metal rejected for recycling because of contamination with rubbish - including medical waste.

Hong Kong officials, alarmed at the idea that the colony might be "deluged" with rubbish, have urged the Chinese authorities to send unwanted shipments direct to the country of origin rather than to the colony, which is involved only as a 'transshipment' port.

Mike Stokoe, Hong Kong's director of environmental protection, says that the colony's laws are to be amended by the end of the year to incorporate the Basle Convention. 